\title{
Systemic effects of salbutamol and salmeterol in patients with asthma
}

\author{
J A Bennett, E T Smyth, I D Pavord, P J Wilding, A E Tattersfield
}

\begin{abstract}
Background - Knowing the extent of the systemic effects of a new $\beta_{2}$ agonist relative to an established drug is important for the prediction and interpretation of side effects. A recent study in which the effect of cumulative doses of salbutamol was compared with single doses of salmeterol suggested that, weight for weight, salmeterol may be up to 10 times more potent than salbutamol. This current study was designed to investigate further the dose equivalence of salmeterol and salbutamol.

Methods - Twelve patients with mild asthma inhaled cumulative doses of placebo, salmeterol $25,50,100$, and $200 \mu \mathrm{g}$, and salbutamol 100, 500, 1000, and $1000 \mu \mathrm{g}$ on separate days at hourly intervals in a randomised double blind crossover study. Changes in forced expiratory volume in one second $\left(F E V_{1}\right)$, heart rate, plasma potassium concentration, systolic and diastolic blood pressure were measured. Dose equivalence was determined as the dose ratio of salmeterol to salbutamol for the $50 \%$ maximum reponse to salbutamol.
\end{abstract}

Results - No important changes occurred in any measurements following placebo. Salmeterol and salbutamol caused a near maximum increase in $\mathrm{FEV}_{1}$ following the first dose so the dose equivalence for the airway effects could not be estimated. Heart rate increased and plasma potassium concentration and diastolic blood pressure decreased in a dose dependent manner following salmeterol and salbutamol, with median dose equivalences for salmeterol compared with salbutamol of $17 \cdot 7,7 \cdot 8$, and $7 \cdot 6$, respectively.

Conclusions - These results confirm that the systemic activity of salmeterol compared with salbutamol is higher than would be expected from in vitro data, particularly for heart rate. Whether this is because of the relatively high dose of salmeterol used or pharmacokinetic differences between the two drugs is uncertain.

(Thorax 1994;49:771-774)

Salmeterol given in a dose of $50 \mu \mathrm{g}$ twice daily provides more effective control of asthma symptoms than salbutamol in doses of $200 \mu \mathrm{g}$ and $400 \mu \mathrm{g}$ four times daily in short term studies. $^{1-3}$ The extent to which the better control with salmeterol is due to its longer duration of action, to a higher relative dose, or to other actions is uncertain. The dose equivalence of salmeterol and salbutamol is still debated and is an important issue in the context of the debate on the safety of $\beta_{2}$ agonists. ${ }^{4-8}$

In our recent dose-response study in which the airway and systemic effects of single doses of salmeterol were compared with cumulative doses of salbutamol in subjects with asthma, salmeterol was 8-10 times more potent than salbutamol weight for weight. ${ }^{9}$ This study suggested that, for systemic effects at least, $50 \mu \mathrm{g}$ salmeterol is equivalent to approximately $500 \mu \mathrm{g}$ salbutamol. This estimate is higher than that obtained from previous studies where dose equivalence was determined from the effect of single doses of salmeterol and salbutamol on lung function..$^{10-12}$

Our previous study was criticised because the response to single doses of salmeterol was compared with that of cumulative doses of salbutamol, different delivery devices were used for salmeterol and salbutamol, and only one measurement was made after salmeterol so that the peak effect may have been missed. We therefore carried out a dose-response study to compare the effects of cumulative doses of salmeterol and salbutamol on separate days, giving both drugs by a large volume spacer and making two measurements of airway and systemic effects after each dose and a third measurement after the final dose.

\section{Methods}

Twelve subjects (four women) aged 29-54 years with asthma but no other significant medical problems were studied. All were lifelong nonsmokers (nine subjects) or ex-smokers with a smoking history of less than five pack years. Subjects had a baseline forced expiratory volume in one second $\left(\mathrm{FEV}_{1}\right)$ greater than $60 \%$ predicted and a rise in $\mathrm{FEV}_{1}$ of at least $15 \%$ after inhalation of $400 \mu \mathrm{g}$ salbutamol. All were taking an inhaled short acting $\beta_{2}$ agonist as required and 11 were taking a regular inhaled steroid (beclomethasone dipropionate or budesonide $400-1600 \mu \mathrm{g}$ ). Subjects gave informed written consent and the study was approved by the Nottingham City Hospital ethics committee.

FEV was measured by a dry bellows spirometer (Vitalograph, Buckingham, UK) with the subject sitting, taking the best of two successive measurements within $100 \mathrm{ml}$. Heart rate was measured over 60 seconds by palpation of the radial pulse. Venous blood samples $(10 \mathrm{ml})$ were taken from a cannula in the forearm (Butterfly 21), placed in a lithium heparin bottle, and centrifuged within 20 minutes of sampling 
at $3000 \mathrm{revs} / \mathrm{min}$ for 15 minutes. Plasma potassium concentration was measured by flame photometry (Olympus AU5000, Olympus Optical Company, Eastleigh, UK).

Subjects were studied at the same time of day on three occasions separated by at least seven days. Inhaled $\beta_{2}$ agonists and caffeine containing drinks were withheld for 12 hours before each visit. Following a 30 minute rest baseline measurements of heart rate, blood pressure, and $\mathrm{FEV}_{1}$ were made, and blood was taken for plasma potassium assay. Subjects were then given increasing doses of placebo, salmeterol $(25,50,100$, and $200 \mu \mathrm{g})$ or salbutamol (100, 500,1000 , and $1000 \mu \mathrm{g}$ ) by metered dose inhaler at hourly intervals according to a randomised, double blind, double dummy, crossover design. Doses of salmeterol, salbutamol, and placebo other than the first dose were administered using a large volume spacing device (Volumatic). At each visit two identical metered dose inhalers (active or placebo) were used, patients receiving one, two, four, and eight puffs from one inhaler and one, five, 10, and 10 puffs from the other. The first inhaler was active on the salmeterol day giving doses of $25,50,100$, and $200 \mu \mathrm{g}$, and the second inhaler was active on the salbutamol day giving doses of $100,500,1000$, and $1000 \mu \mathrm{g}$. Two, four, or five puffs were activitated into the spacer before two inhalations; for higher doses this was repeated on a second occasion. Patients held their breath for 10 seconds after each inhalation. Each drug dose was administered over a period of three minutes. Further measurements were taken at 15 and 60 minutes after each dose in the same order as at baseline, and a final set of measurements was taken 120 minutes after the last dose of drug. The maximum change after each dose was used in the analysis. The study was stopped if symptoms became troublesome or if the heart rate rose above 140 beats/minute. Patients

Table 1 Mean (SD) baseline values of heart rate, FEV , plasma potassium concentration, and blood pressure on the three study days

\begin{tabular}{|c|c|c|c|c|c|}
\hline & $\begin{array}{l}\text { Heart } \\
\text { rate } \\
\text { (bpm) }\end{array}$ & $\begin{array}{l}F E V_{1} \\
\text { (1) }\end{array}$ & $\begin{array}{l}\text { Plasma } \\
\text { potassium } \\
(\text { mmol } / l)\end{array}$ & $\begin{array}{l}\text { Systolic } \\
B P \\
(\mathrm{~mm} \mathrm{Hg})\end{array}$ & $\begin{array}{l}\text { Diastolic } \\
B P \\
(m m \mathrm{Hg})\end{array}$ \\
\hline Salbutamol & $\begin{array}{l}69 \cdot 8 \\
(10 \cdot 6)\end{array}$ & $\begin{array}{l}2 \cdot 74 \\
(1 \cdot 14)\end{array}$ & $\begin{array}{l}3.98 \\
(0 \cdot 21)\end{array}$ & $\begin{array}{l}121 \\
(7 \cdot 5)\end{array}$ & $\begin{array}{l}79 \\
(5 \cdot 2)\end{array}$ \\
\hline Salmeterol & $\begin{array}{l}67.9 \\
(10 \cdot 1)\end{array}$ & $\begin{array}{l}2.69 \\
(1.05)\end{array}$ & $\begin{array}{l}4 \cdot 0 \\
(0 \cdot 28)\end{array}$ & $\begin{array}{l}119 \\
(7 \cdot 5)\end{array}$ & $\begin{array}{l}79 \\
(7 \cdot 2)\end{array}$ \\
\hline Placebo & $\begin{array}{l}66 \cdot 3 \\
(12 \cdot 1)\end{array}$ & $\begin{array}{l}2.68 \\
(1.05)\end{array}$ & $\begin{array}{l}4 \cdot 0 \\
(0 \cdot 27)\end{array}$ & $\begin{array}{l}119 \\
(8 \cdot 1)\end{array}$ & $\begin{array}{l}78 \\
(5 \cdot 2)\end{array}$ \\
\hline
\end{tabular}

Table 2 Mean (SE) maximal change in effect seen with salmeterol, salbutamol, and placebo for heart rate, $F E V_{1}$, plasma potassium concentration, and diastolic blood pressure

\begin{tabular}{|c|c|c|c|c|}
\hline & $\begin{array}{l}\text { Heart } \\
\text { rate } \\
\text { (bpm) }\end{array}$ & $\begin{array}{l}F E V_{I} \\
\text { (1) }\end{array}$ & $\begin{array}{l}\text { Plasma } \\
\text { potassium } \\
(\text { mmol } / l)\end{array}$ & $\begin{array}{l}\text { Diastolic } \\
\text { BP } \\
(\mathrm{mm} \mathrm{Hg})\end{array}$ \\
\hline Salbutamol & $\begin{array}{l}4 \cdot 92 \\
(2 \cdot 21)\end{array}$ & $\begin{array}{l}0.57 \\
(0.08)\end{array}$ & $\begin{array}{l}-0.41 \\
(0.06)\end{array}$ & $\begin{array}{l}-6 \cdot 5 \\
(2.03)\end{array}$ \\
\hline Salmeterol & $\begin{array}{l}15 \cdot 08 \\
(2 \cdot 36)\end{array}$ & $\begin{array}{l}0.62 \\
(0.08)\end{array}$ & $\begin{array}{l}-0.52 \\
(0 \cdot 10)\end{array}$ & $\begin{array}{l}-8.83 \\
(1.92)\end{array}$ \\
\hline Placebo & $\begin{array}{l}1.83 \\
(2 \cdot 45)\end{array}$ & $\begin{array}{l}0.05 \\
(0.09)\end{array}$ & $\begin{array}{l}-0 \cdot 13 \\
(0 \cdot 12)\end{array}$ & $\begin{array}{l}-1 \cdot 74 \\
(2 \cdot 20)\end{array}$ \\
\hline
\end{tabular}

remained in the department until symptoms settled and heart rate had fallen below 110 beats/minute.

\section{DATA ANALYSIS}

Analysis of variance was used to compare baseline measurements of $\mathrm{FEV}_{1}$, heart rate, plasma potassium concentration, and blood pressure; symptoms were compared by the Fisher exact probability test.

Individual values for dose equivalence were calculated by plotting the response to each dose of salmeterol and salbutamol on a log doseresponse curve and drawing a line of regression through the linear part of the curve taking the last three readings. Dose equivalence was measured at $50 \%$ of the maximal effect seen with salbutamol by comparing the dose of salbutamol and salmeterol required to achieve this effect. Individual dose equivalences were not normally distributed and are described as median and interquartile range.

Since the earlier doses of salbutamol may not have been effective at the time of administration of the final dose because of its shorter duration of action, we also calculated a minimum dose equivalence assuming that at the time of each drug administration only $50 \%$ of the preceding dose was active. This gave a cumulative dose range of $100,500,1250$, and $1500 \mu \mathrm{g}$ for salbutamol.

The log dose-responses for the two drugs were tested by analysis of variance to determine whether they deviated from parallelism. ${ }^{13}$

The generalised interactive modelling (GLIM) statistical package was used for statistical analysis.

\section{Results}

All patients completed all three dose-response studies. There were no significant differences in baseline measurements of $\mathrm{FEV}_{1}$, heart rate, plasma potassium concentration, and systolic and diastolic blood pressure (table 1), and no important changes in any of these measurements were seen after placebo (table 2). None of the log dose-reponses for the two drugs was found to deviate from parallelism (all $\mathrm{p}>0.05$ ).

CHANGE IN FEV There was a near maximal increase in $\mathrm{FEV}_{1}$ following the first dose of both salmeterol $(0.42 \mathrm{l})$ and salbutamol $(0.41 \mathrm{l})$ and progressively smaller increases after further doses (fig 1). The maximum increase was 0.621 and 0.571 respectively (table 2 ).

CHANGE IN HEART RATE, PLASMA POTASSIUM, AND BLOOD PRESSURE

Salmeterol and salbutamol caused a largely dose dependent increase in heart rate and fall in plasma potassium concentration and diastolic blood pressure (fig 1). The median dose equivalence for salmeterol compared with salbutamol was $17 \cdot 7$ (interquartile range $9 \cdot 2-21 \cdot 8$ ) for heart rate, 7.8 (interquartile range $3.7-10.7$ ) for 
Figure 1 Mean (SE) change from baseline in $F E V_{1}$, heart rate, plasma potassium concentration, and diastolic blood pressure with increasing doses of salmeterol ( $\mathbf{\Delta})$ and salbutamol (assuming a total cumulative dose of minimal estimate assuming a total cumulative dose of $1500 \mu \mathrm{g} \square-\square[$ see methods]). $2600 \mu \mathrm{g}-\mathbf{\square}$ or $a$

列

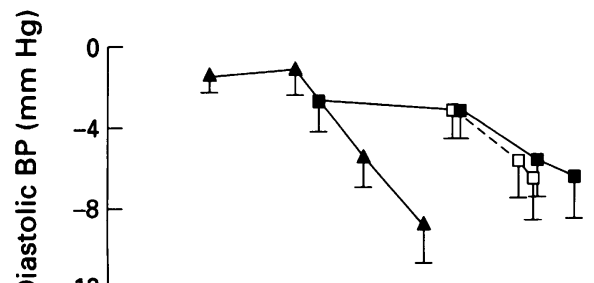

$\begin{array}{ll}\square & -12 \\ & 0.8\end{array}$

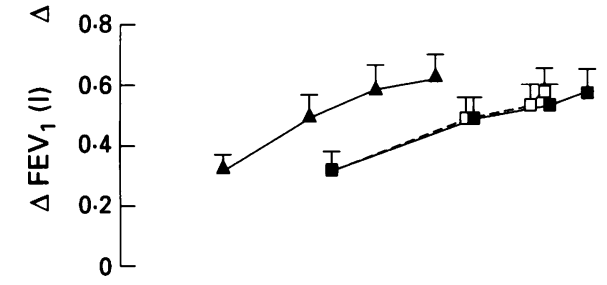

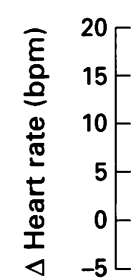
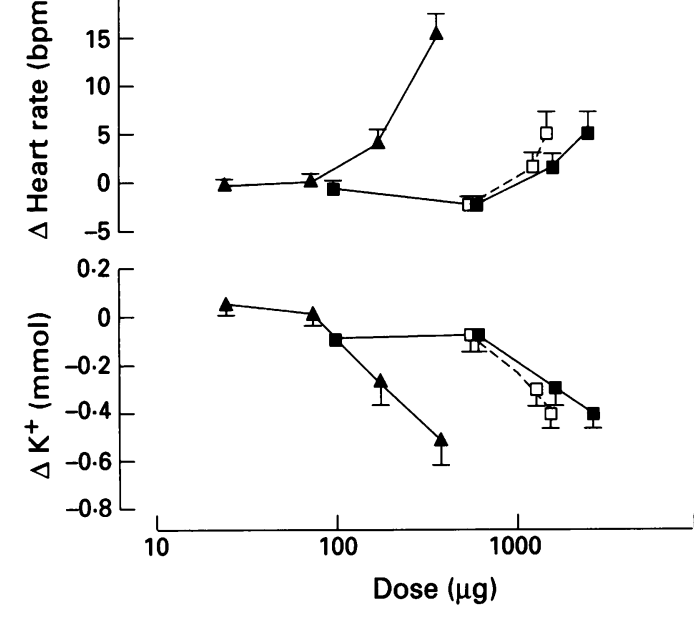

Figure 2 Mean $(S E)$ change from baseline in $F E V_{1}$, heart rate, plasma potassium concentration, and diastolic blood pressure with increasing time following the last dose of salmeterol $(\mathbf{\Delta})$ and salbutamol ( $\mathbf{D})$.

\section{列}
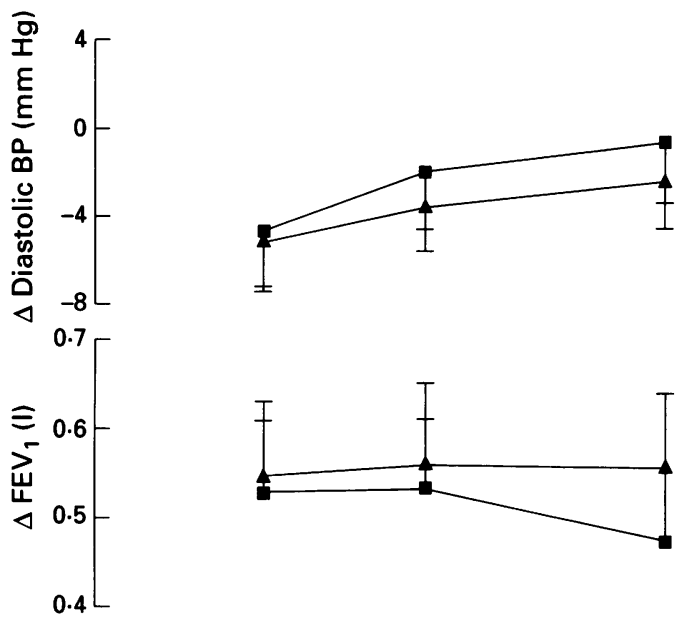

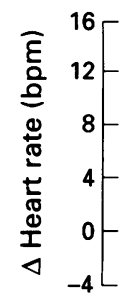

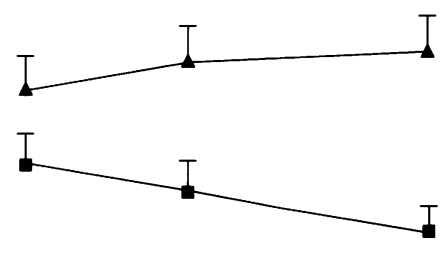

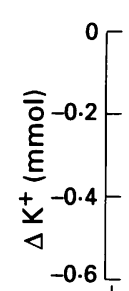

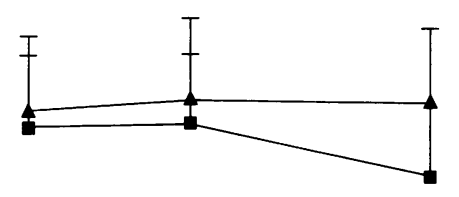

Tremor and palpitations were significantly more common following salmeterol (four and three patients) and salbutamol (four and three patients) than placebo $(0$ and 0$)$. Other side effects included headache (three salmeterol, three salbutamol, and three placebo), flushing (one salbutamol), and wheezing (one placebo).

\section{Discussion}

The new long acting $\beta_{2}$ agonist salmeterol is available for twice daily administration. Clinical trials suggest that patients with asthma are better controlled by a twice daily dose of $50 \mu \mathrm{g}$ salmeterol than by four times daily administration of $200 \mu \mathrm{g}$ and $400 \mu \mathrm{g}$ salbutamol. ${ }^{1-3}$ The extent to which this beneficial effect of salmeterol is the result of a higher relative dose, its longer duration of action, or other actions is uncertain. Our recent study in which the response of cumulative doses of salbutamol was compared with non-cumulative doses of salmeterol suggested that higher dosage might be an important factor since the dose equivalence of the two drugs on systemic measures was between 8 and $10 .{ }^{9}$ These data imply that $50 \mu \mathrm{g}$ of salmeterol twice daily would be roughly equivalent to $400-500 \mu \mathrm{g}$ salbutamol up to four hourly. This may be important if the use of high doses of $\beta_{2}$ agonists is causally associated with an increased risk of death..$^{5-8}$

One criticism raised of our previous study was that only one measurement was made after each dose of drug and that the maximum drug effect may have been missed. In the present study measurements were made 20 and 60 minutes after each dose with a further measurement 120 minutes after the last dose. After the final dose of salmeterol there was little difference in the effects seen at 60 and 120 minutes. With salbutamol the maximum effect was seen at 20 minutes following the final dose with a gradual decrease in effect at 60 and 120 minutes. These results suggest that we had measured the maximum effects of both drugs after each dose. The responses to both salmeterol and salbutamol in our study are very 
similar to those seen in other studies. Maconochie et al found a similar increase in heart rate ( 16 beats $/ \mathrm{min}$ ) and fall in plasma potassium concentration $(0.45 \mathrm{mmol} / \mathrm{l})$ following a single $400 \mu \mathrm{g}$ dose of salmeterol in normal subjects ${ }^{14}$ to that seen in our study with cumulative doses (total dose $375 \mu \mathrm{g}$ ). The magnitude of change for all measurements following cumulative doses of salbutamol was similar to that seen in our previous studies. ${ }^{915}$

We were unable to estimate the dose equivalence of salbutamol and salmeterol for the airway effects since a near maximum response was achieved with the lowest dose of both drugs. The dose equivalence for fall in plasma potassium concentration and diastolic blood pressure was 7-8, which agrees closely with estimates from our previous study; the dose equivalence for heart rate was greater at 17.7. It is possible that the dose equivalence is an overestimate since the doses of salbutamol may not be truly cumulative because of its shorter duration of action. Any effect this might have on our estimate of dose equivalence would have been small - for example, assuming the final dose of salbutamol to be $1500 \mu \mathrm{g}(50 \%$ of the penultimate dose and the final dose) rather than $2600 \mu \mathrm{g}$ (the total dose) would reduce the dose equivalence for heart rate from $17 \cdot 7$ to $12 \cdot 2$.

The greater systemic effects of salmeterol relative to salbutamol in vivo may be due to increased systemic bioavailability, increased dose, or differences in $\beta$ receptor selectivity. The dose equivalence for systemic $\beta_{2}$ mediated effects, such as the fall in serum potassium levels, are higher than would be expected from studies in vitro where salmeterol is approximately five times more potent than salbutamol on a weight for weight basis. ${ }^{1617}$ This suggests that the systemic dose for salmeterol is high compared with salbutamol. Whether this is because of the high dose administered or differences in systemic availability is difficult to determine without knowing the relative effect of the two drugs on the airways. Systemic effects of salbutamol are largely due to the inhaled rather than the swallowed portion of the drug, ${ }^{18}$ partly because it undergoes first pass metabolism. ${ }^{19}$ The fate of the swallowed portion of salmeterol is unknown and it is possible that its greater systemic effects are due to decreased first pass metabolism. Differences in oropharyngeal or lung deposition of the two drugs are unlikely to account for our findings as both drugs were administered using the same delivery system.

Dose equivalence for heart rate was higher than that of plasma potassium concentration. This finding was surprising as there is evidence that the chronotropic response to $\beta$ agonists is predominantly $\beta_{2}$ mediated, ${ }^{20}$ although some $\beta_{1}$ effect cannot be excluded. In vitro salmeterol is at least as $\beta_{2}$ selective as salbutamol. ${ }^{21}{ }^{22}$ Our findings suggest that salmeterol may be less $\beta_{2}$ selective than salbutamol; alternatively, the lipophilic nature of salmeterol may result in more rapid absorption from the lung into bronchial veins or the buccal mucosa and perhaps a higher transient concentration at cardiac $\beta_{2}$ receptors.

In conclusion we have shown that, for sys- temic effects, salmeterol is 7-17 times more potent than salbutamol. Further work is needed to determine whether this is a result of pharmacokinetic differences or differences in dose. Whatever the mechanism, the difference between the two in their propensity to increase heart rate may be relevant to the concerns about mortality with salmeterol compared with salbutamol which have been raised in the recent post-marketing surveillance study. ${ }^{23}$

We thank Mr A Wisniewski and Mrs J Williams for help with the study and Mrs S Pacey for randomisation and coding of the drugs

1 Ullman A, Hedner J, Svedmyr N. Inhaled salmeterol and salbutamol in asthmatic patients. Am Rev Respir Dis 1990;142:571-5.

2 Pearlman DS, Chervinsky P, LaForce C, Seltzer JM, Southern DL, Kemp JP, et al. A comparison of salmeterol with albuterol in the treatment of mild-to-moderate asthma. $N$ Engl f Med 1992;327:1420-5.

3 Lundback B, Rawlinson DW, Palmer JBD. Twelve months comparison of salmeterol and salbutamol as dry powder formulations in asthmatic patients. Thorax 1993; 48: 148-53.

4 Cheung D, Timmers MK, Zwinderman AH, Bel EH, Dijkman JH, Sterk PJ. Long term effects of a long-acting $\beta_{2}$ adrenoceptor agonist, salmeterol, on airway responsiveness in patients with mild asthma. $N$ Engl $f$ Med 1992;327: in patients

5 Crane J, Platt A, Jackson R, Ball M, Pearce N, Burgess C, et al. Prescribed fenoterol and death from asthma in New Zealand, 1981-83: case-control study. Lancet 1989;i: 917-22.

6 Pearce N, Grainger J, Atkinson M, Crane J, Burgess C, Culling C, et al. Case-control study of prescribed fenoterol and death from asthma in New Zealand, 1977-81. Thorax and death from

7 Grainger J, Woodman K, Pearce N, Crane J, Burgess C, Keane A, et al. Prescribed fenoterol and death from asthma in New Zealand, 1981-87: a further case-control study. Thorax 1991;46:105-11.

8 Spitzer WO, Suissa S, Ernst P, Horwitz RI, Habbick B, Cockcroft $\mathrm{D}$, et al. The use of $\beta$-agonists and the risk of death and near death from asthma. $N$ Engl $f$ Med 1992;326:501-6.

9 Smyth ET, Pavord ID, Wong CS, Wisniewski AFZ, Williams J, Tattersfield AE. Interaction and dose equivalence of salbutamol and salmeterol in patients with asthma. $B M F$ 1993;306:543-5.

10 Ullman A, Svedmyr N. Salmeterol, a new long acting $\beta_{2}$ adrenoceptor agonist: comparison with salbutamol in adult asthmatic patients. Thorax 1998;43:674-8.

11 Bierman CW, Kemp JP, Cuss FM. Dose-response study of salmeterol, a new long acting beta ${ }_{2}$ agonist. Thorax 1989;44:850P

12 Sandstrom T, Frederiksen B, Rosenhall L, Sandstrom B. Salmeterol - a lose response study with a long acting $\beta_{2^{-}}$agonist. Am Rev Respir Dis 1989;139:64A.

13 Armitage P. Statistical methods in medical research. Oxford: Blackwell Scientific Publications: 1971

14 Maconochie JG, Forster JK. Dose response study with highdose inhaled salmeterol in healthy subjects. $\mathrm{Br} f$ Clin Pharmacol 1992;33:342-5.

15 Wong CS, Pavord ID, Williams J, Britton JR, Tattersfield AE. Bronchodilator, cardiovascular, and hypokalaemic effects of fenoterol, salbutamol, and terbutaline in asthma. Lancet 1990;336:1396-9.

16 Ball DI, Brittain RT, Coleman RA, Denyer LH, Jack D, Johnson $M$, et al. Salmeterol, a novel, long-acting $\beta_{2}$ adrenoceptor agonist: characterization of pharmacological activity in vitro and vivo. Br $\mathcal{F}$ Pharmacol 1991;104:665-71.

17 Butchers P, Cousins SA, Vardey CJ. Salmeterol, a potent and long acting inhibitor of the release of inflammatory and spasmogenic mediators from human lung. $\mathrm{Br} \mathcal{F}$ Pharmacol 1987;92:745.

18 Collier JG, Dobbs RJ, Williams I. Salbutamol aerosol causes a tachycardia due to the inhaled rather than swallowed a taction. Br F Clin Pharmacol 1980;9:273-4.

19 Morgan DJ, Paull JD, Richmond BH, Wilson-Evered E, Ziccone SP. Pharmacokinetics of intravenous and oral salbutamol and its sulphate conjugate. Brf Clin Pharmacol salbutamol and its

20 Lipworth BJ, Brown RA, McDevitt DG. Assessment of airways, tremor and chronotropic reponses to inhaled salbutamol in the quantification of beta-2 adrenoceptor blockade. Br $\mathcal{F}$ Clin Pharmacol 1989;28:95-102.

21 Ball DI, Coleman RA, Denyer LH, Nials AT, Sheldrick KE. In vitro characterisation of the beta -adrenoceptor agonist, salmeterol. Br $\mathcal{F}$ Pharmacol 1987;88:591.

22 Ball DI, Coleman RA, Denyer LH, Nials AT, Sheldrick KE. Bronchodilator activity of salmeterol, a long acting $\beta_{2}$ adrenoceptor agonist. Br f Pharmacol 1987;90:746.

23 Castle W, Fuller R, Hall J, Palmer J. Serevent nationwide surveillance study: comparison of salmeterol with salbutamol in patients who require regular bronchodilator treatment. BMF 1992;306:1034-7. 